\title{
Airway recommendations for perioperative patients during the COVID-19 pandemic: a
}

\section{scoping review}

Alexa Grudzinski MD, ${ }^{1}$ Billy Sun MD, ${ }^{1}$ MengQi Zhang BSc, ${ }^{2,4}$ Agnes Crnic MD,${ }^{1}$ Abdul H Djokhdem MD, ${ }^{2}$ Mary Hanna MD, ${ }^{1}$ Joshua Montroy MSc, ${ }^{4}$ Laura V Duggan MD, ${ }^{1}$ Gavin M. Hamilton MD MSc, ${ }^{1}$ Dean A Fergusson MHA, PhD, ${ }^{4,5}$ Sylvain Boet MD, $\mathrm{PhD}^{1,3,6,7,8,9} *$ Daniel I McIsaac MD MPH, ${ }^{1,5,10}$ * Manoj M Lalu MD PhD ${ }^{1,4,11} *$

1. Department of Anesthesiology and Pain Medicine, University of Ottawa, The Ottawa Hospital, Ottawa, ON, Canada

2. Faculty of Medicine, University of Ottawa, Ottawa, ON, Canada

3. Clinical Epidemiology Program, Ottawa Hospital Research Institute, Ottawa, ON, Canada

4. Blueprint Translational Research Group, Clinical Epidemiology Program, Ottawa Hospital Research Institute, Ottawa, ON, Canada

5. School of Epidemiology and Public Health, University of Ottawa, Ottawa, Canada

6. Department of Innovation in Medical Education, University of Ottawa, Ottawa, ON, Canada

7. Francophone Affairs, Faculty of Medicine, University of Ottawa, Ottawa, ON, Canada

8. Institut du Savoir Montfort, Ottawa, ON, Canada

9. Faculty of Education, University of Ottawa, Ottawa, ON, Canada

10. AIMS Research Group, Ottawa Hospital Research Institute, Ottawa, Ontario, Canada

11. Department of Cellular and Molecular Medicine, University of Ottawa, Ottawa, Canada

$*=$ co-senior authors

Corresponding author:

Manoj M. Lalu MD, PhD, FRCPC

Department of Anesthesiology and Pain Medicine

The Ottawa Hospital

Room B307

1053 Carling Ave, Mail Stop 249

Ottawa, Ontario, Canada, K1Y 4E9

E-mail address: mlalu@toh.ca

ORCID 0000-0002-0322-382X

Disclosures: DIM, LVD, MML, and SB are supported by The Ottawa Hospital Anesthesia Alternate Funds Association. DIM, MML, and SB hold University of Ottawa Clinical Research Chairs.

Short Title: Perioperative airway recommendations during COVID-19 
medRxiv preprint doi: https://doi.org/10.1101/2021.07.30.21261372; this version posted August 4, 2021. The copyright holder for this preprint (which was not certified by peer review) is the author/funder, who has granted medRxiv a license to display the preprint in perpetuity.

All rights reserved. No reuse allowed without permission.

\section{Implication Statement}

We synthesized COVID-19 related perioperative airway management recommendations found on anesthesia society websites. Substantial agreement was found between recommendations (e.g. personal protective equipment). However, discordance also existed between recommendations. This, along with a lack of reported rigour in guideline development, highlight the need for a coordinated response to future pandemics. 
medRxiv preprint doi: https://doi.org/10.1101/2021.07.30.21261372; this version posted August 4, 2021. The copyright holder for this preprint (which was not certified by peer review) is the author/funder, who has granted medRxiv a license to display the preprint in perpetuity.

All rights reserved. No reuse allowed without permission.

\begin{abstract}
:
Purpose: Numerous guideline recommendations for airway and perioperative management during the COVID-19 pandemic have been published. We identified, synthesized, and compared guidelines intended for anesthesiologists.
\end{abstract}

Source: Member society websites of the World Federation of Societies of Anesthesiologists and the European Society of Anesthesiologists were searched. Recommendations focused on perioperative airway management of patients with proven or potential COVID-19 disease were included. Accelerated screening was used; data extraction was performed by one reviewer and verified by a second. Data was organized into themes based on perioperative phase of care.

Principal Findings: Thirty unique sets of recommendations were identified. None reported methods for systematically searching or selecting evidence to be included. Four were updated following initial publication. For induction and airway management, most recommended minimizing personnel and having the most experienced anesthesiologist perform tracheal intubation. Significant congruence was observed amongst recommendations that discussed personal protective equipment. Of those that discussed tracheal intubation methods, most (96\%) recommended video laryngoscopy, while discordance existed regarding use of flexible bronchoscopy. Intraoperatively, 23\% suggested specific anesthesia techniques and most (63\%) recommended a specific operating room for patients with COVID-19. Postoperatively, a minority discussed extubation procedures $(33 \%)$, or care in the recovery room $(40 \%)$. Nontechnical considerations were discussed in $27 \%$ and psychological support for healthcare providers in $10 \%$. 
medRxiv preprint doi: https://doi.org/10.1101/2021.07.30.21261372; this version posted August 4, 2021. The copyright holder for this preprint (which was not certified by peer review) is the author/funder, who has granted medRxiv a license to display the preprint in perpetuity.

All rights reserved. No reuse allowed without permission.

Conclusion: Recommendations for perioperative airway management of patients with COVID19 overlap to a large extent. However, we also identified significant differences. This may reflect the absence of a coordinated response towards studying and establishing best-practices in perioperative patients with COVID-19.

Registration: Open Science Framework (https://osf.io/a2k4u/) 


\section{Introduction}

A defining feature of COVID-19 has been its rapid human-to-human transmission, ${ }^{1}$ largely through respiratory droplets and aerosols. Based mainly on retrospective evidence from the 2003 Severe Acute Respiratory Syndrome (SARS) epidemic, aerosol-generating medical procedures (AGMPs) such as tracheal intubation and extubation, and close proximity to the airway of perioperative patients were thought to increase the infection risk of anesthesiologists. ${ }^{2}$ In response, there has been a rapid proliferation of guidelines, recommendations, opinion pieces, checklists, and cognitive aids for the airway and perioperative management of patients with COVID-19. For the purposes of this review, we have labelled these diverse sources of information as 'recommendations'. These recommendations have allowed perioperative health systems, anesthesiology societies, and departments of anesthesiology to establish policies and protocols to optimize the safety of both patients and healthcare providers.

The initial, rapid rise in recommendations may appropriately reflect regional differences in perioperative environments and resources. However, the publication of a large number of recommendations may limit knowledge translation, confuse providers, and potentially make it more difficult to adopt specific protocols. Contradictory information or discrepancies between recommendations may also decrease the perceived credibility of their sources, further delaying standardization of care. Indeed, the choice overload hypothesis would suggest that a larger number of choices may have negative motivating and affective consequences for behavior change. ${ }^{3}$

Given what we perceived to be a large number of guidance documents being published, we systematically identified and synthesized these perioperative airway management recommendations. This scoping review aimed to identify and review the breadth of 
medRxiv preprint doi: https://doi.org/10.1101/2021.07.30.21261372; this version posted August 4, 2021. The copyright holder for this preprint (which was not certified by peer review) is the author/funder, who has granted medRxiv a license to display the preprint in perpetuity.

All rights reserved. No reuse allowed without permission.

recommendations for anesthesiologists and compare their content. Our scoping review also provides an important opportunity to assess one aspect of our community's response to the COVID-19 pandemic and assist in establishing consistency while decreasing unnecessary practice variation as we prepare for the endemic phase of this disease. 
medRxiv preprint doi: https://doi.org/10.1101/2021.07.30.21261372; this version posted August 4, 2021. The copyright holder for this preprint (which was not certified by peer review) is the author/funder, who has granted medRxiv a license to display the preprint in perpetuity.

All rights reserved. No reuse allowed without permission.

\section{Methods}

Our proposed scoping review followed a standard framework first defined by Arksey and O'Malley, ${ }^{4}$ expanded by Levac et $a l,{ }^{5}$ and summarized by the Joanna Briggs Institute. ${ }^{6}$ Our protocol was posted a priori on Open Science Framework (https://osf.io/a2k4u/). Our final review is reported in accordance with the PRISMA extension for scoping reviews (PRISMAScR) (checklist in Appendix 1, Supplemental Digital Content). ${ }^{7}$

\section{Inclusion Criteria}

To be eligible for inclusion in the review, sources had to meet the following criteria:

1) The target population included adult patients requiring surgery. Patient populations undergoing both cardiac and non-cardiac surgery were included.

2) Recommendations were for the perioperative airway management of patients with potential or proven COVID-19 disease. "Perioperative" was defined as any patient expected to have surgery, having surgery, or recently post-surgery, who are directly cared for by an anesthesiologist or anesthesia care provider.

\section{Exclusion Criteria}

Sources that provided recommendations for perioperative airway management of patients with COVID-19 exclusively for obstetric, pediatric, or non-operative (e.g. endoscopy) populations were excluded. Sources that focused on airway management in non-operating room settings (intensive care units, trauma bay, hospital ward, prehospital care) were excluded.

\section{Literature Search}

A search was conducted of national anesthesia organization webpages. We used the list of 136 member societies (representing 150 countries) of the World Federation of Societies of 
medRxiv preprint doi: https://doi.org/10.1101/2021.07.30.21261372; this version posted August 4, 2021. The copyright holder for this preprint (which was not certified by peer review) is the author/funder, who has granted medRxiv a license to display the preprint in perpetuity.

All rights reserved. No reuse allowed without permission.

Anesthesiologists (WFSA) as well as the European Society of Anesthesiology and Intensive Care (ESAIC). Additionally, we searched the websites of other relevant organizations such as the Anesthesia Patient Safety Foundation and Safe Airway Society. Homepages of each society were opened in Google Chrome and, if needed, the translation function was activated. The homepage for each organization was reviewed for any information regarding COVID airway management guidelines, along with searches for "COVID" and "coronavirus" where webpage search functions were available. We extracted data from English, French, Croatian, Serbian, or Bosnian language material (languages spoken by the review team).

\section{Data Extraction}

References were uploaded to DistillerSR (Evidence Partners, Ottawa, Canada), an auditready cloud-based program that assists with the design and conduct of systematic reviews. Full texts of included recommendations were screened independently and in duplicate. Initial disagreements were resolved by further discussion or, if necessary, a third senior author was consulted.

\section{Data Charting}

The data abstraction form focussed on five general themes: PPE, airway equipment, nontechnical skills, induction and extubation methods, and mental health of healthcare providers. Questions were refined via an iterative process involving all investigators and the data extraction form was then piloted using five of the included published recommendations (Appendix 2). Senior investigators reviewed the data abstraction of the five published recommendations to ensure the data abstracted was consistent with the research question and purpose as 
medRxiv preprint doi: https://doi.org/10.1101/2021.07.30.21261372; this version posted August 4, 2021. The copyright holder for this preprint (which was not certified by peer review) is the author/funder, who has granted medRxiv a license to display the preprint in perpetuity.

All rights reserved. No reuse allowed without permission.

recommended by Levac et al. ${ }^{5}$ Data from included recommendations were transcribed into DistillerSR by one reviewer; a second reviewer independently verified accuracy of the data input. All data were verified by at least one team member with perioperative clinical experience.

To synthesize the results, data extracted was organized into five a priori determined themes based on perioperative phase of care: pre-operative, induction/airway management, intraoperative, extubation/recovery, and general recommendations (i.e. not specific to a phase of care). Data were exported to Excel (Microsoft, Redmond, USA). Frequencies of items are reported.

\section{Deviations from Protocol}

In keeping with scoping review methodology, iterative changes were made in our protocol and have been documented in our registration. We originally searched MEDLINE, LitCovid, and Google for guidelines and recommendations surrounding the perioperative airway management of patients with COVID-19. These searches were conducted with the assistance of an information specialist (Risa Shorr, MLS, Ottawa Hospital Learning Services). As we updated our search, the number of captured publications proliferated. Number of records from our initial search increased exponentially from 94 in March 2020 to over 4000 by July 2020. In consultation with our information specialist, we modified our search to maintain feasibility resulting in 885 citations. Even with this modified search, 4951 records were retrieved by July 2021. Following screening, the majority of relevant publications identified were authored by small groups of individuals unassociated with national or international anesthesiology organizations. As such, our study group decided to restrict our search to websites of member societies of the WFSA and ESAIC to ensure that recommendations included in this scoping 
medRxiv preprint doi: https://doi.org/10.1101/2021.07.30.21261372; this version posted August 4, 2021. The copyright holder for this preprint (which was not certified by peer review) is the author/funder, who has granted medRxiv a license to display the preprint in perpetuity.

All rights reserved. No reuse allowed without permission.

review were widely accessible and endorsed by national organizations or anesthesia societies, therefore potentially representing the highest quality and evidence-based recommendations as well as perceived as the most credible by clinicians for practice change. Furthermore, a single reviewer assessed whether included publications used systematic methods to search for evidence or described the criteria used for selecting evidence. 


\section{Results}

A total of 176 publications were retrieved from anesthesia society websites. Following screening, 30 publications, each representing a unique set of recommendations, met our eligibility criteria and were included in our analysis (Table 1).

\section{Recommendation Characteristics}

Original dates of publication were reported in 28/30 (93\%), ranging from February 2020 to August 2020. We found updated versions for four publications (13\%), with the most recent being updated in June 2021. Of these thirty, $23(77 \%)$ referred to their publication as "recommendations", and five (17\%) referred to their publication as "guidelines". None of the included publications used systematic methods to search for evidence or described the criteria used for selecting evidence. The majority (20/30, 67\%) specified that the target patient population of their publication was confirmed COVID-positive patients, whereas 10/30 (33\%) did not specify a target population (i.e., confirmed positive, suspected or asymptomatic, tested or untested).

\section{Phase of Care: Preoperative}

A minority $(7 / 30,23 \%)$ of publications discussed the preoperative patient assessment. These included preoperative hygiene processes (e.g. hand hygiene) (7/30, 23\%), and PPE for clinicians during preoperative assessment (4/30, 13\%; Figure 2). Five publications (17\%) recommended amendments to the usual pre-anesthetic history and physical examination; four suggested the addition of temperature measurement. Other recommendations included in these seven publications were a detailed risk assessment history (e.g., travel, COVID-19-specific symptoms and treatment), emphasis on chest examination and other organ systems affected by COVID-19 disease, and consideration of imaging such as chest x-ray or CT scan (especially in 
medRxiv preprint doi: https://doi.org/10.1101/2021.07.30.21261372; this version posted August 4, 2021. The copyright holder for this preprint (which was not certified by peer review) is the author/funder, who has granted medRxiv a license to display the preprint in perpetuity.

All rights reserved. No reuse allowed without permission.

emergencies or if COVID status is indeterminate). One publication suggested the use of telemedicine when possible. Approximately half $(14 / 30,47 \%)$ of publications recommended PPE for patients, specifically the donning of a surgical/procedure mask.

\section{Phase of Care: Induction/Airway Management}

The majority of publications $(24 / 30,80 \%)$ provided recommendations for specific team members and roles during anesthesia induction and airway management (Figure 3). Of these 24, 20 advised minimizing the number of personnel in the operating room to only those directly involved in establishing in the airway. Six publications provided specific suggestions for clearly defined roles (e.g., primary anesthesiologist, a second/assisting anesthesiologist, one "runner" within the OR, and one "runner" outside the operating room or in the ante-room). One article recommended a team leader distinct from the primary anesthesiologist to coordinate the team, manage drugs, observe monitoring, and provide airway assistance if necessary. The majority of publications 19/30 (63\%) provided recommendations on who should perform tracheal intubation. All 24 publications recommended tracheal intubation be performed by the most experienced anesthesiologist. Of note, two of these publications provided recommendations to consider excluding staff who may be vulnerable (e.g., immunocompromised) from the airway team.

$\underline{P P E}$

The majority of publications $(26 / 30,87 \%)$ discussed PPE for anesthesia induction and airway management. PPE included gloves (23 publications), isolation gowns (20 publications), N95 masks (23 publications), and goggles or face shield (22 publications). Two publications discussed self-check for the donning/doffing of PPE in this phase of care, and six discussed PPE spotter-checks. 
medRxiv preprint doi: https://doi.org/10.1101/2021.07.30.21261372; this version posted August 4, 2021. The copyright holder for this preprint (which was not certified by peer review) is the author/funder, who has granted medRxiv a license to display the preprint in perpetuity.

All rights reserved. No reuse allowed without permission.

\section{Airway Equipment}

The majority of publications $(23 / 30,77 \%)$ provided specific suggestions for airway equipment, of which $22(73 \%)$ recommended the use of video laryngoscopy. Thirteen publications specifically recommended against the use of flexible bronchoscopy for tracheal intubation; conversely, two publications supported its use. The majority of publications (22/30, $73 \%$ ) provided specific suggestions surrounding use of a filter on the anesthetic circuit, with seven recommending a high efficiency particulate absorbing filter and four recommending a heat and moisture exchanger filter. Most publications $(21 / 30,70 \%)$ suggested the use of an intraoperative suction system, with 14 of these specifically describing a closed-suction system.

\section{Preoxygenation}

The majority of publications $(20 / 30,67 \%)$ discussed preoxygenation with all highlighting adequate preoxygenation specifically to avoid manual ventilation post-induction. Some suggested techniques to minimize potential aerosolization during preoxygenation included use of low flow oxygen (e.g. $<6 \mathrm{~L} / \mathrm{min}$ ), two-handed facemask ventilation, a well-sealed/fitted facemask, and the application of wet gauze over the patient's nose and mouth to block secretions.

\section{$\underline{\text { Induction }}$}

Specific processes for the induction of anesthesia were mentioned in 24/30 (80\%) publications, all of which recommended rapid sequence induction. Four publications specified dosing of neuromuscular blocking agents (rocuronium $>1.2 \mathrm{mg} / \mathrm{kg}$ total body weight or $>1.5 \mathrm{mg} / \mathrm{kg}$ ideal body weight, succinylcholine $1.5 \mathrm{mg} / \mathrm{kg}$ total body weight). Two specifically recommended that sufficient time be provided for onset of neuromuscular blockade. Three publications discussed the use of pharmacologic adjuncts during induction of anesthesia to 
medRxiv preprint doi: https://doi.org/10.1101/2021.07.30.21261372; this version posted August 4, 2021. The copyright holder for this preprint (which was not certified by peer review) is the author/funder, who has granted medRxiv a license to display the preprint in perpetuity.

All rights reserved. No reuse allowed without permission.

reduce the risk of aerosolization. Suggested agents included atropine or glycopyrrolate for secretion reduction and prophylactic anti-emetics.

\section{Difficult Airway}

Less than half of publications mentioned approaches to a difficult airway $(11 / 30,37 \%)$. With respect to awake tracheal intubation, two publications recommended against use of awake tracheal intubation techniques, while three stated awake techniques could be used if required. With respect to airway rescue techniques, four recommended the use of a supraglottic airway as a rescue device for hypoxia and four discussed the use of cricothyroidotomy in a cannotintubate-cannot-oxygenate scenario.

\section{Phase of Care: Intraoperative}

\section{Type of Anesthesia}

A minority of publications $(7 / 30,23 \%)$ recommended a specific type of anesthetic technique (Figure 4). Of these seven, four suggested the use of regional/neuraxial techniques when possible. Of note, most publications recommended the donning of a surgical/procedure mask on non-intubated patients during surgical procedures.

\section{Operating Rooms}

Nineteen of thirty (63\%) of publications mentioned having a specific operating room for patients with COVID-19. Of these publications, 14 recommended using a negative pressure operating room (Figure 4). In situations where a negative pressure operating room was not available, several publications recommended turning off the positive pressure and air conditioning systems commonly present in standard operating rooms. Labelling COVID operating rooms with specific signage was recommended in 16 publications. PPE for the intraoperative phase of case was discussed in two publications. Operating room disinfection was 
medRxiv preprint doi: https://doi.org/10.1101/2021.07.30.21261372; this version posted August 4, 2021. The copyright holder for this preprint (which was not certified by peer review) is the author/funder, who has granted medRxiv a license to display the preprint in perpetuity.

All rights reserved. No reuse allowed without permission.

mentioned in 9/30 (30\%) publications. Of these, three suggested implementing a waiting period between operations (e.g. 30-60 min). Two publications recommended a minimum rate of air exchange (12 and 25 exchanges per hour).

\section{Equipment Cleaning}

Nine publications (30\%) commented on anesthesia machine cleaning. Of these publications, one recommended the use of disposable anesthetic machine covers and four recommended the use of "hospital approved" or EPA-approved disinfectant for anesthesia machine cleaning. Seven publications recommended that high-touch surfaces of the anesthetic machine be cleaned and disinfected and 20/30 (67\%) recommended disinfection of equipment and/or the use of single-use equipment. Proper disposal of medical waste was mentioned in 14/30 (47\%, e.g., a designated, labelled COVID-19 waste bin).

\section{Phase of Case: Postoperative}

\section{Extubation}

Extubation was discussed in 10/30 (33\%) publications, with recommendations for the specific extubation procedure provided in six (Figure 5). The most common suggestion for extubation involved the use of anti-tussive techniques. Specifically, one article recommended use of spontaneously breathing deep extubation and laryngeal mask airway exchange using a closed system.

\section{$\underline{P P E}$}

PPE for extubation was mentioned in 4/30 (13\%) publications, the most common including the donning of gloves, an isolation gown, an N95 mask, and goggles or face shield 
medRxiv preprint doi: https://doi.org/10.1101/2021.07.30.21261372; this version posted August 4, 2021. The copyright holder for this preprint (which was not certified by peer review) is the author/funder, who has granted medRxiv a license to display the preprint in perpetuity.

All rights reserved. No reuse allowed without permission.

(Figure 5). Doffing processes were discussed in 19/30 (61\%) publications (Figure 5). Amongst these publications, 13 highlighted the importance of proper hand hygiene after doffing. Five publications recommended a designated environment for doffing, four highlighted the need to avoid self-contamination (i.e., touching their own face/hair) and three recommended the presence of a spotter/coach.

\section{Post-anesthesia Care Unit}

Fourteen publications $(47 \%)$ discussed patient transport to recovery and twelve $(40 \%)$ discussed care in the post-anesthesia care unit. General recommendations included wearing appropriate PPE, minimizing transport time, donning of a mask by the patient, and the use of a non-permeable patient cover during transport. Recommendations for tracheally intubated patients included minimizing the number and duration of breathing circuit disconnections, adequate paralysis, and clamping of the endotracheal tube during movement from one closed ventilation system to another to prevent aerosolization. One publication suggested a single dose of a 5hydroxytryptamine receptor antagonist to prevent postoperative nausea and vomiting. A minority of publications discussed PPE during recovery room care $(4 / 30,13 \%)$ the most common of which was the use of gloves ( 2 publications), an isolation gown ( 2 publications), a surgical/procedure mask (2 publications), and eye protection ( 2 publications).

\section{Support, Surveillance, and Non-Technical Considerations}

Psychological support for healthcare providers (HCPs) was discussed in 3/30 (10\%) publications. Suggestions included having available psychologic support services for HCPs, having adequate time off-work between shifts, and preparing for mental and physical fatigue. Surveillance of HCPs for potential COVID-19 symptoms and exposures was discussed in 5/30 (17\%) of publications, of which two recommended HCPs keep a clinical logbook. Non-technical 
medRxiv preprint doi: https://doi.org/10.1101/2021.07.30.21261372; this version posted August 4, 2021. The copyright holder for this preprint (which was not certified by peer review) is the author/funder, who has granted medRxiv a license to display the preprint in perpetuity. All rights reserved. No reuse allowed without permission.

considerations were discussed by $8 / 30$ (27\%) publications (Figure 5). Of these, four recommended the use of a pre-brief/pre-operative checklist and two recommended a debrief. Five publications highlighted the importance of clear, concise, or closed-loop communication, and four identified the use of PPE as an important barrier to effective communication. Twenty (67\%) publications recommended training. Of those that recommended training, the majority $(15 / 20,75 \%)$ recommended PPE training (donning, doffing). 8/20 (40\%) recommended simulation-based training and 8/20 (40\%) specifically recommended infection control training. 
medRxiv preprint doi: https://doi.org/10.1101/2021.07.30.21261372; this version posted August 4, 2021. The copyright holder for this preprint (which was not certified by peer review) is the author/funder, who has granted medRxiv a license to display the preprint in perpetuity.

All rights reserved. No reuse allowed without permission.

\section{Discussion}

We synthesized peri-operative airway management recommendations during the COVID19 pandemic. The majority of identified recommendations had a strong focus on the induction/airway and intra-operative phases of care. Despite the number and scope of publications reviewed, there was substantial agreement between societies on numerous aspects of COVID-19 perioperative airway management. Most recommendations included similar PPE recommendations, approaches to tracheal intubation including minimizing personnel present and suggested having the most experienced airway manager perform tracheal intubation. There was substantial congruence regarding specific tracheal intubation techniques, with most publications recommending a rapid sequence technique with video laryngoscopy. It is reassuring that the majority of societies provided congruent recommendations on multiple key components of perioperative airway management and care. Consistency in recommendations provided to anesthesiologists may have eased clinical decision-making and improved adherence to best safety practices in the COVID-19 era.

Although most publications provide similar suggestions, heterogeneity remains. As an example, while some publications specifically recommended against fibreoptic tracheal intubation in the difficult COVID-19 airway, others supported its use. Furthermore, there was substantial discordance in recommendations for both extubation techniques as well as PPE use during extubation. These conflicting recommendations may result in significant confusion for the individual practitioner, department or healthcare system when adopting best-practice protocols, particularly in the acute setting where not all perioperative factors are controlled. Additionally, there appears to be a lack of guidance surrounding appropriate PPE to be worn during the intraoperative phase of care, specifically during the period after tracheal intubation. Moreover, there 
medRxiv preprint doi: https://doi.org/10.1101/2021.07.30.21261372; this version posted August 4, 2021. The copyright holder for this preprint (which was not certified by peer review) is the author/funder, who has granted medRxiv a license to display the preprint in perpetuity.

All rights reserved. No reuse allowed without permission.

is a lack of consensus regarding how long induction/airway management PPE should be worn during the operative case. Our findings highlight the absence of a unified consensus for perioperative airway management in patients with COVID-19.

Similar to a previous study, most of the recommendations identified in our review were not developed in a methodologically rigorous manner. ${ }^{8}$ For instance, no included recommendations used systematic methods to search for evidence nor did any clearly describe the criteria used for selecting evidence (two major components of evidence-based guideline development). ${ }^{9}$ This is likely a result of the relatively rapid nature in which these recommendations were developed and published, especially in the early days of the pandemic wherein our collective understanding of the virulence, routes or duration of transmission, and life cycle of the SARS-CoV-2 virus was limited. The lack of methodologic rigour in the development of the included recommendations may limit their successful uptake and implementation. ${ }^{10}$ However, when a new virus becomes the basis of a pandemic, recommendations prior to such knowledge being available, are at times required. The Campbell Inquiry, a federal government inquiry into the healthcare response to SARS in 2003 provides some principles for approaching a new public healthcare threat. Judge Campbell emphasized the use of the precautionary principle, which dictates that when there are two conflicting recommendations during an unclear healthcare threat, that the safer approach be followed. ${ }^{11}$ This results in frontline healthcare providers trusting that the recommendations made by national or society structures are to protect them. Once more evidence is gleaned, or other protections such as vaccination are widespread, recommendations should change to reflect the current situation.

Of great concern is the lack of updates to the majority of recommendations. As our knowledge and understanding of COVID-19 continues to grow, these documents have not kept 
medRxiv preprint doi: https://doi.org/10.1101/2021.07.30.21261372; this version posted August 4, 2021. The copyright holder for this preprint (which was not certified by peer review) is the author/funder, who has granted medRxiv a license to display the preprint in perpetuity.

All rights reserved. No reuse allowed without permission.

pace. For instance, significant concerns have been raised surrounding aerosolization of COVID19 during tracheal intubation; however, recent evidence has suggested that tracheal intubation in paralysed patients may not be aerosol-generating ${ }^{12}$, unlike the era of SARS when patients were oftentimes not paralysed during tracheal intubation. ${ }^{2}$ High-resolution environmental monitoring in ultraclean operating rooms has suggested that detectable aerosols during tracheal intubation might be 15-fold lower than with extubation, and detectable aerosols during extubation might be 35-fold lower than a volitional cough. ${ }^{12}$ As another example, recommendations generally suggested that negative pressure rooms may provide greater protection during aerosol-generating medical procedures performed in patients with COVID-19. ${ }^{13-16}$ However, negative pressure rooms have since been suggested to contribute to the increased the risk of developing pulmonary aspergillosis (which is commonly observed in patients with COVID-19). ${ }^{17,} 18$ Considering the rapidly emerging evidence, it is not surprising that outdated recommendations remain readily accessible. This undoubtedly contributes to ongoing confusion about, and lack of adherence to, the most up-to-date best practices. Interestingly, our original searches of MEDLINE, LitCovid, and Google identified a significant number of recommendations authored by small groups of individuals unassociated with national or international anesthesia societies. Given that these documents are unlikely to be developed and supported by anesthesia organizations or societies, the utility of continuing to publish such recommendations at this point in the pandemic is unclear. We would suggest that the time and resources expended on these recommendations may provide greater benefit if directed towards developing an international set of consensus-based guidelines, for both care providers and patients alike. We would also suggest a systematic international registry to curate access and management to pandemic-related guidelines. This will allow for outdated recommendations to be quickly identified. 
medRxiv preprint doi: https://doi.org/10.1101/2021.07.30.21261372; this version posted August 4, 2021. The copyright holder for this preprint (which was not certified by peer review) is the author/funder, who has granted medRxiv a license to display the preprint in perpetuity.

All rights reserved. No reuse allowed without permission.

Our study has limitations. Firstly, our results provide an overview of the current literature rather than answer a single, predefined question. Secondly, the recommendations included in our scoping review were not comprehensively assessed for methodologic quality (since this is not usually conducted for scoping reviews), although we would expect that included recommendations would likely score poorly in both methodological rigour and transparency of development.

Reflecting on our experiences with the COVID-19 pandemic, our study should inform future efforts to improve and streamline the pandemic response. A few central groups of critical care specialists were able to both create and organize emerging evidence and facilitate the creation of internationally applicable guidelines which could be locally modified as needed. For example, the REMAP-CAP and RECOVERY trials provided a global research platform to efficiently adapt to the COVID-19 pandemic, and rapidly evaluate various treatments in an expeditious manner. ${ }^{19-21}$ Similar international, multicentre initiatives within the perioperative research space were seldom observed, representing an important avenue of exploration to improve preparedness for future pandemics. Early synthesis and organization of evidence without redundancy in efforts will facilitate development of a judicious response to future pandemics. Our scoping review may be considered as one of the first needed steps to learn from experience. Just like individuals learn from reflexive practice, ${ }^{22}$ institutions are increasingly becoming learning organizations and we would like to suggest that specialty societies may adopt the same approach to become "learning societies" to optimize future patient care. ${ }^{23}$ By learning the available lessons during the COVID-19 pandemic, we may dramatically reduce the lead time to robust recommendations in healthcare while potentially avoiding the deleterious impact of pandemic-related restrictions. For example, the widespread cancellation of semi-urgent and 
medRxiv preprint doi: https://doi.org/10.1101/2021.07.30.21261372; this version posted August 4, 2021. The copyright holder for this preprint (which was not certified by peer review) is the author/funder, who has granted medRxiv a license to display the preprint in perpetuity. All rights reserved. No reuse allowed without permission.

elective surgeries in Ontario at the onset of the pandemic occurred in anticipation of a surge in patients with COVID-19. ${ }^{24}$ The complete impact of these increased wait times on population health has yet to be determined, and is ongoing. ${ }^{25}$ An important first step involves analyzing and identifying gaps in our current methods of creating and updating clinical practice guidelines, with a particular focus on how these processes should be refined in the context of a global pandemic and as COVID-19 evolves into an endemic disease. 
medRxiv preprint doi: https://doi.org/10.1101/2021.07.30.21261372; this version posted August 4, 2021. The copyright holder for this preprint

(which was not certified by peer review) is the author/funder, who has granted medRxiv a license to display the preprint in perpetuity.

All rights reserved. No reuse allowed without permission.

Acknowledgements: The authors thank Risa Shorr, MLS (Learning Services, The Ottawa

Hospital) for conducting the systematic searches. 


\section{REFERENCES}

1 Li Q, Guan X, Wu P, et al. Early Transmission Dynamics in Wuhan, China, of Novel Coronavirus-Infected Pneumonia. N Engl J Med 2020; 382: 1199-207.

2 Tran K, Cimon K, Severn M, Pessoa-Silva CL, Conly J. Aerosol generating procedures and risk of transmission of acute respiratory infections to healthcare workers: a systematic review. PLoS One 2012; 7: e35797.

3 Chernev A, Böckenholt U, Goodman J. Choice overload: A conceptual review and metaanalysis. Journal of Consumer Psychology 2015; 25: 333-58.

4 Arksey H, O'Malley L. Scoping studies: towards a methodological framework. Int J Soc Res Methodol 2005; 8: 19-32.

5 Levac D, Colquhoun H, O'Brien KK. Scoping studies: advancing the methodology. Implement Sci 2010; 5: 69.

6 Joanna Briggs Institute. Scoping Review Network [cited July 20 2021]. Available from URL; https://jbi.global/scoping-review-network/.

7 Tricco AC, Lillie E, Zarin W, et al. PRISMA Extension for Scoping Reviews (PRISMAScR): Checklist and Explanation. Ann Intern Med 2018; 169: 467-73.

8 Ong S, Lim WY, Ong J, Kam P. Anesthesia guidelines for COVID-19 patients: a narrative review and appraisal. Korean J Anesthesiol 2020; 73: 486-502.

9 Brouwers MC, Kho ME, Browman GP, et al. AGREE II: advancing guideline development, reporting and evaluation in health care. CMAJ 2010; 182: E839-42. 
medRxiv preprint doi: https://doi.org/10.1101/2021.07.30.21261372; this version posted August 4, 2021. The copyright holder for this preprint

(which was not certified by peer review) is the author/funder, who has granted medRxiv a license to display the preprint in perpetuity.

All rights reserved. No reuse allowed without permission.

10 Francke AL, Smit MC, de Veer AJ, Mistiaen P. Factors influencing the implementation of clinical guidelines for health care professionals: a systematic meta-review. BMC Med Inform Decis Mak 2008; 8: 38.

11 Crosby L, Crosby E. Applying the precautionary principle to personal protective equipment (PPE) guidance during the COVID-19 pandemic: did we learn the lessons of SARS? Can J Anaesth 2020; 67: 1327-32.

12 Brown J, Gregson FKA, Shrimpton A, et al. A quantitative evaluation of aerosol generation during tracheal intubation and extubation. Anaesthesia 2021; 76: 174-81.

13 Alhazzani W, Moller MH, Arabi YM, et al. Surviving Sepsis Campaign: Guidelines on the Management of Critically Ill Adults with Coronavirus Disease 2019 (COVID-19). Crit Care Med 2020; 48: e440-e69.

14 Sorbello M, El-Boghdadly K, Di Giacinto I, et al. The Italian coronavirus disease 2019 outbreak: recommendations from clinical practice. Anaesthesia 2020; 75: 724-32.

15 Cook TM, El-Boghdadly K, McGuire B, McNarry AF, Patel A, Higgs A. Consensus guidelines for managing the airway in patients with COVID-19: Guidelines from the Difficult Airway Society, the Association of Anaesthetists the Intensive Care Society, the Faculty of Intensive Care Medicine and the Royal College of Anaesthetists. Anaesthesia 2020; 75: 785-99.

16 Thiruvenkatarajan V, Wong DT, Kothandan H, et al. Airway Management in the Operating Room and Interventional Suites in Known or Suspected COVID-19 Adult Patients: A Practical Review. Anesth Analg 2020; 131: 677-89. 
medRxiv preprint doi: https://doi.org/10.1101/2021.07.30.21261372; this version posted August 4, 2021. The copyright holder for this preprint

(which was not certified by peer review) is the author/funder, who has granted medRxiv a license to display the preprint in perpetuity.

All rights reserved. No reuse allowed without permission.

17 Alanio A, Delliere S, Fodil S, Bretagne S, Megarbane B. Prevalence of putative invasive pulmonary aspergillosis in critically ill patients with COVID-19. Lancet Respir Med 2020; 8: e48-e9.

18 Ichai P, Saliba F, Baune P, Daoud A, Coilly A, Samuel D. Impact of negative air pressure in ICU rooms on the risk of pulmonary aspergillosis in COVID-19 patients. Crit Care 2020; $24: 538$.

19 REMAP-CAP response to the COVID-19 pandemic [cited July 20 2021]. Available from URL; https://www.remapcap.org/coronavirus.

20 Remap-Cap Investigators, Gordon AC, Mouncey PR, et al. Interleukin-6 Receptor Antagonists in Critically Ill Patients with Covid-19. N Engl J Med 2021; 384: 1491-502.

21 RECOVERY Trial [cited July 20 2021]. Available from URL; https://www.recoverytrial.net/.

22 Schön DA. The Reflective Practioner: How Professionals Think in Action. London: Routledge; 1992.

23 Garvin DA. Building a Learning Organization. Harvard Business Review, July - August ed: Harvard Business School Publishing; 1993.

24 Wang J, Vahid S, Eberg $M$, et al. Clearing the surgical backlog caused by COVID-19 in Ontario: a time series modelling study. CMAJ 2020; 192: E1347-E56. 
medRxiv preprint doi: https://doi.org/10.1101/2021.07.30.21261372; this version posted August 4, 2021. The copyright holder for this preprint (which was not certified by peer review) is the author/funder, who has granted medRxiv a license to display the preprint in perpetuity.

All rights reserved. No reuse allowed without permission.

25 Uimonen M, Kuitunen I, Paloneva J, Launonen AP, Ponkilainen V, Mattila VM. The impact of the COVID-19 pandemic on waiting times for elective surgery patients: A multicenter study. PLoS One 2021; 16: e0253875. 
medRxiv preprint doi: https://doi.org/10.1101/2021.07.30.21261372; this version posted August 4, 2021. The copyright holder for this preprint (which was not certified by peer review) is the author/funder, who has granted medRxiv a license to display the preprint in perpetuity.

All rights reserved. No reuse allowed without permission.

\section{Figure Legends}

Figure 1. PRISMA flow diagram of recommendation selection.

Figure 2. Summary of pre-operative assessment recommendations from the included publications $(\mathrm{n}=30)$.

Figure 3. Summary of induction and airway instrumentation recommendations from the included publications $(\mathrm{n}=30)$.

Figure 4. Summary of intraoperative management recommendations from the included publications $(\mathrm{n}=30)$.

Figure 5. Summary of post-operative management recommendations from the included publications $(\mathrm{n}=30)$. 


\begin{tabular}{|c|c|c|c|}
\hline Society/Organization & Article Title & Country of Origin & $\begin{array}{l}\text { Target Patient } \\
\text { Population }\end{array}$ \\
\hline Australian Society of Anesthetists & $\begin{array}{l}\text { Anaesthesia and caring for } \\
\text { patients during the COVID-19 } \\
\text { outbreak }\end{array}$ & Australia & NS \\
\hline Safe Airway Society & $\begin{array}{l}\text { Consensus statement: Safe } \\
\text { Airway Society principles of airway } \\
\text { management and tracheal } \\
\text { intubation specific to the COVID- } \\
19 \text { adult patient group }\end{array}$ & $\begin{array}{l}\text { Australia, New } \\
\text { Zealand }\end{array}$ & $\begin{array}{l}\text { Tested Suspected, } \\
\text { Confirmed Positive }\end{array}$ \\
\hline Safe Airway Society & $\begin{array}{l}\text { COVID-19 Airway Management } \\
\text { Infographics }\end{array}$ & $\begin{array}{l}\text { Australia, New } \\
\text { Zealand }\end{array}$ & $\begin{array}{l}\text { Tested Suspected, } \\
\text { Confirmed Positive }\end{array}$ \\
\hline $\begin{array}{l}\text { Society for Anesthesia and Resuscitation of } \\
\text { Belgium }\end{array}$ & $\begin{array}{l}\text { SARB recommendations for the } \\
\text { anesthetic management of } \\
\text { patients suspected of being } \\
\text { infected or infected by the new } \\
\text { coronavirus initially named } 2019 \text { - } \\
\text { nCoV }\end{array}$ & Belgium & $\begin{array}{l}\text { Tested Suspected, } \\
\text { Confirmed Positive }\end{array}$ \\
\hline $\begin{array}{l}\text { Association of Medical Practitioners } \\
\text { Anesthesiologists-reanimatologists (UDMAR) }\end{array}$ & $\begin{array}{l}\text { Coronavirus - guidance for } \\
\text { anaesthesia and perioperative } \\
\text { care providers }\end{array}$ & $\begin{array}{l}\text { Bosnia and } \\
\text { Herzegovina }\end{array}$ & $\begin{array}{l}\text { Tested Suspected, } \\
\text { Confirmed Positive }\end{array}$ \\
\hline Canadian Anesthesiologists' Society & $\begin{array}{l}\text { Canadian Anesthesiologists' } \\
\text { Society } \\
\text { COVID-19 Recommendations } \\
\text { during Airway Manipulation }\end{array}$ & Canada & $\begin{array}{l}\text { Tested Suspected, } \\
\text { Confirmed Positive }\end{array}$ \\
\hline Canadian Anesthesiologists' Society & $\begin{array}{l}\text { Reinstitution of Elective } \\
\text { Operations following COVID-19 }\end{array}$ & Canada & $\begin{array}{l}\text { Untested } \\
\text { Asymptomatic, Tested } \\
\text { Suspected, Confirmed } \\
\text { Positive }\end{array}$ \\
\hline $\begin{array}{l}\text { Chinese Society of Anesthesiology, Chinese } \\
\text { Association of Anesthesiologists }\end{array}$ & $\begin{array}{l}\text { Perioperative Management of } \\
\text { Patients Infected with the Novel } \\
\text { Coronavirus }\end{array}$ & China & $\begin{array}{l}\text { Tested suspected, } \\
\text { Confirmed positive }\end{array}$ \\
\hline Chinese Society of Anesthesiology & $\begin{array}{l}\text { Chinese Society of } \\
\text { Anesthesiology Expert Consensus } \\
\text { on Anesthetic Management of } \\
\text { Cardiac Surgical Patients With }\end{array}$ & China & $\begin{array}{l}\text { Untested } \\
\text { Asymptomatic, Tested } \\
\text { Suspected, Confirmed } \\
\text { Positive }\end{array}$ \\
\hline
\end{tabular}




\begin{tabular}{|c|c|c|c|}
\hline & $\begin{array}{l}\text { Suspected or Confirmed } \\
\text { Coronavirus Disease } 2019\end{array}$ & & \\
\hline $\begin{array}{l}\text { Société Française d'Anesthésie et de } \\
\text { Réanimation }\end{array}$ & $\begin{array}{l}\text { Proposals for the anesthetic } \\
\text { management of a patient } \\
\text { suspected or infected with } \\
\text { Coronavirus COVID-19 }\end{array}$ & France & NS \\
\hline $\begin{array}{l}\text { Société Française d'Anesthésie et de } \\
\text { Réanimation }\end{array}$ & $\begin{array}{l}\text { Coronavirus } 2019 \text { et période } \\
\text { périopératoire } \\
\text { (COVID-19) }\end{array}$ & France & NS \\
\hline $\begin{array}{l}\text { Société Française d'Anesthésie et de } \\
\text { Réanimation }\end{array}$ & $\begin{array}{l}\text { Preconisations pour l'adaptation } \\
\text { de l'offre de soins en anesthesie- } \\
\text { reanimation dans le contexte de } \\
\text { pandemie de covid-19-fiches- } \\
\text { pratiques }\end{array}$ & France & $\begin{array}{l}\text { Untested } \\
\text { Asymptomatic, Tested } \\
\text { Suspected, Confirmed } \\
\text { Positive }\end{array}$ \\
\hline $\begin{array}{l}\text { Société Française d'Anesthésie et de } \\
\text { Réanimation }\end{array}$ & $\begin{array}{l}\text { Preconisations pour l'adaptation } \\
\text { de l'offre de soins en anesthesie- } \\
\text { reanimation dans le contexte de } \\
\text { pandemie de covid-19 }\end{array}$ & France & NS \\
\hline $\begin{array}{l}\text { Italian Society of Anaesthesia, Analgesia, } \\
\text { Resuscitation and Intensive Care (SIAARTI) }\end{array}$ & $\begin{array}{l}\text { Surgery in COVID-19 patients: } \\
\text { operational directives }\end{array}$ & Italy & $\begin{array}{l}\text { Tested Suspected, } \\
\text { Confirmed Positive }\end{array}$ \\
\hline Kenya Society of Anesthesiologists & $\begin{array}{l}\text { Kenya Society Of } \\
\text { Anaesthesiologists } \\
\text { Safe Anaesthesia } \\
\text { Perioperative Preparation And } \\
\text { Handling Of Confirmed Or Highly } \\
\text { Suspected Covid-19 Patients } \\
\text { (Protection in high risk aerosol } \\
\text { generating procedures). }\end{array}$ & Kenya & $\begin{array}{l}\text { Untested } \\
\text { Asymptomatic, Tested } \\
\text { Suspected, Confirmed } \\
\text { Positive }\end{array}$ \\
\hline Korean Society of Anesthesiologists & $\begin{array}{l}\text { Management Of Critical Covid-19 } \\
\text { Disease After Confirmation Of } \\
\text { Tests }\end{array}$ & Korea & NS \\
\hline $\begin{array}{l}\text { Malaysian Society Of Anaesthesiologists \& } \\
\text { Malaysian Society Of Intensive Care }\end{array}$ & $\begin{array}{l}\text { Recommendations For } \\
\text { Management Of Anaesthesia And } \\
\text { Intensive Care Services } \\
\text { In Preparation Of Worsening Of } \\
\text { The Covid } 2019 \text { Pandemic, }\end{array}$ & Malaysia & NS \\
\hline
\end{tabular}




\begin{tabular}{|c|c|c|c|}
\hline & $\begin{array}{l}\text { Guidelines On Management Of } \\
\text { Corona Virus Disease } 2019 \\
\text { (Covid-19) In Surgery }\end{array}$ & & \\
\hline $\begin{array}{l}\text { Moroccan Society of Anesthesia and } \\
\text { Resuscitation }\end{array}$ & $\begin{array}{l}\text { Recommandations De Bonnes } \\
\text { Pratiques Relatives A La Prise En } \\
\text { Charge Des Cas Suspects Ou } \\
\text { Confirmés Covid-19 }\end{array}$ & Morocco & $\begin{array}{l}\text { Tested Suspected, } \\
\text { Confirmed Positive }\end{array}$ \\
\hline $\begin{array}{l}\text { Serbian Association of Anesthesiologists and } \\
\text { Intensivists }\end{array}$ & $\begin{array}{l}\text { Coronavirus - guidance for } \\
\text { anaesthesia and perioperative } \\
\text { care providers }\end{array}$ & Serbia & $\begin{array}{l}\text { Tested Suspected, } \\
\text { Confirmed Positive }\end{array}$ \\
\hline South African Society of Anaesthesiologists & $\begin{array}{l}\text { Recommendations for the } \\
\text { management of anaesthesia and } \\
\text { surgery for Elective Procedures }\end{array}$ & South Africa & NS \\
\hline South African Society of Anaesthesiologists & $\begin{array}{l}\text { SASA Recommendations on } \\
\text { Personal Protective Equipment } \\
\text { (PPE) for anaesthesia providers } \\
\text { during the COVID-19 pandemic }\end{array}$ & South Africa & NS \\
\hline $\begin{array}{l}\text { Taiwan Society of Anesthesiologists, Advanced } \\
\text { Airway Committee }\end{array}$ & $\begin{array}{l}\text { Endotracheal Intubation in } \\
\text { Patients With COVID-19 Infection: } \\
\text { Expert Panel-Based Consensus } \\
\text { Recommendations }\end{array}$ & Taiwan & NS \\
\hline Association of Anesthesiologists of Uganda & $\begin{array}{l}\text { AAU/ICSU Covid-19 Airway } \\
\text { management guidelines }\end{array}$ & Uganda & $\begin{array}{l}\text { Untested } \\
\text { Asymptomatic, } \\
\text { Confirmed Positive }\end{array}$ \\
\hline Association of Anaesthetists & $\begin{array}{l}\text { Anaesthetic Management of } \\
\text { Patients During a COVID-19 } \\
\text { Outbreak }\end{array}$ & United Kingdom & $\begin{array}{l}\text { Untested } \\
\text { Asymptomatic, Tested } \\
\text { Suspected, Confirmed } \\
\text { Positive }\end{array}$ \\
\hline $\begin{array}{l}\text { Association of Anaesthetists, The Faculty of } \\
\text { Intensive Care, Intensive Care Society, Royal } \\
\text { College of Anaesthetists }\end{array}$ & $\begin{array}{l}\text { COVID-19 airway management } \\
\text { principles }\end{array}$ & United Kingdom & NS \\
\hline American Society of Anesthesiologists & $\begin{array}{l}\text { COVID-19 Information for Health } \\
\text { Care Professionals }\end{array}$ & United States & $\begin{array}{l}\text { Tested Suspected, } \\
\text { Confirmed Positive }\end{array}$ \\
\hline American Society of Anesthesiologists & $\begin{array}{l}\text { COVID-19 Information for Health } \\
\text { Care Professionals }\end{array}$ & United States & $\begin{array}{l}\text { Tested Suspected, } \\
\text { Confirmed Positive }\end{array}$ \\
\hline Anesthesia Patient Safety Foundation, American & Perioperative Considerations for & United States & Untested \\
\hline
\end{tabular}




\begin{tabular}{|l|l|l|l|}
\hline $\begin{array}{l}\text { Society of Anesthesiologists, American } \\
\text { Association of Nurse Anesthetists, American } \\
\text { Academy of Anesthesiologist Assistants }\end{array}$ & $\begin{array}{l}\text { the 2019 Novel Coronavirus } \\
\text { (COVID-19) }\end{array}$ & $\begin{array}{l}\text { Asymptomatic, Tested } \\
\text { Suspected, Confirmed } \\
\text { Positive }\end{array}$ & $\begin{array}{l}\text { Tested Suspected, } \\
\text { Confirmed Positive }\end{array}$ \\
\hline $\begin{array}{l}\text { World Federation of Societies of } \\
\text { Anaesthesiologists }\end{array}$ & $\begin{array}{l}\text { World Federation Of Societies of } \\
\text { Anaesthesiologists - Coronavirus }\end{array}$ & N/A & $\begin{array}{l}\text { Tested Suspected, } \\
\text { Confirmed Positive }\end{array}$ \\
\hline $\begin{array}{l}\text { World Federation of Societies of } \\
\text { Anaesthesiologists }\end{array}$ & $\begin{array}{l}\text { Perioperative management of } \\
\text { suspected/ confirmed cases of } \\
\text { COVID-19 }\end{array}$ & N/A & \\
\hline
\end{tabular}

Table 1. Study characteristics of included publications 
Records identified from:

Websites $(n=176)$

Records screened

$(n=175)$

Records excluded

$(n=112)$

Records not retrieved

$(n=0)$

Records sought for retrieval $(n=63)$

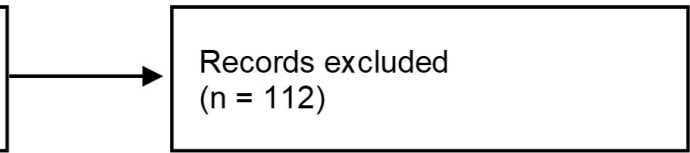

올

Records assessed for eligibility $(n=63)$
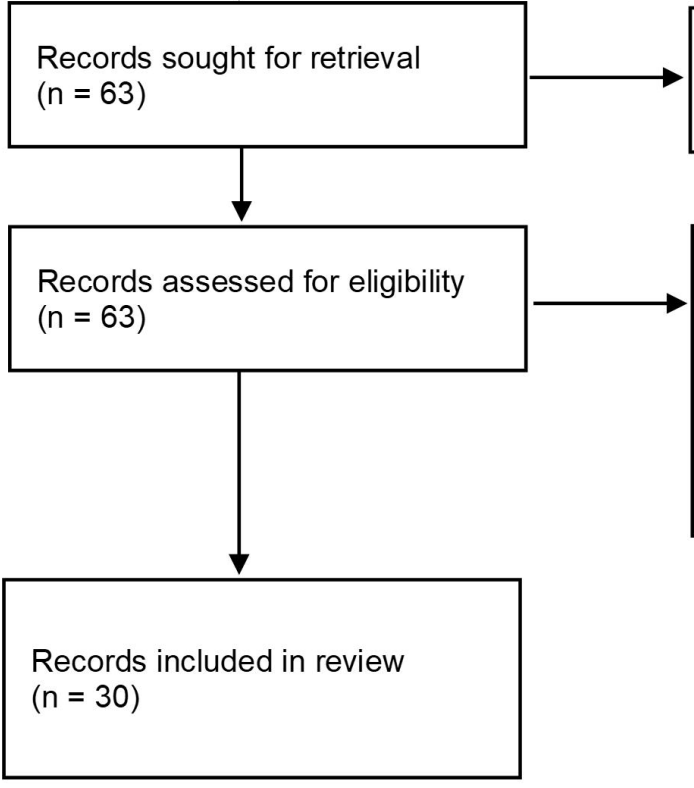

Records excluded:

Other $(n=13)$

Non-operative $(n=11)$

Duplicate $(n=4)$

Obstetric $(n=3)$

Pediatric $(n=2)$

Records included in review $(n=30)$ 


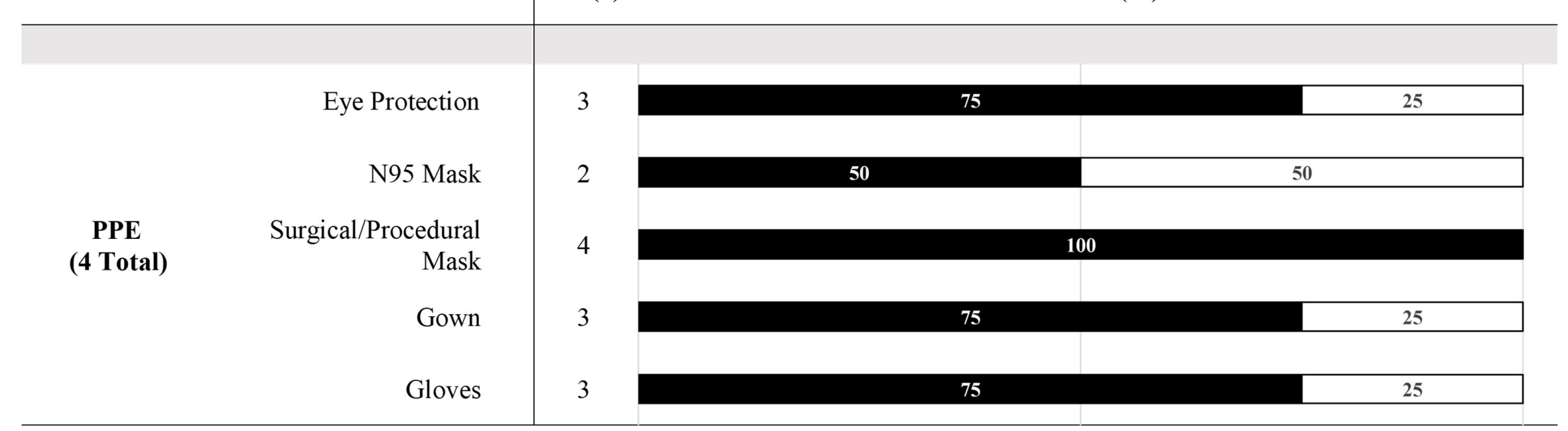

Legend: black = yes $($ reported $) ;$ white $=$ no $($ not reported $)$ 
General

Airway management

PPE

(26 Total)

Induction

(24 Total)

Airway

Equipment

(23 Total)

Difficult

Airway

(11 Total)

(21 Total)

Closed Suction

Other Filter

Filter

(22 Total)

Minimize \# of Individuals

(24 Total)

Most Experienced Intubator (19 Total)

Powered Air Purifying Respirator

Shoe Cover

Double Gloves

Eye Protection

N95 Mask

Surgical/Procedural Mask

Gown

Gloves

Rapid Sequence Induction

Video Laryngoscope

Advise Against Bronchoseope/Fiberoptic Scope

Bronchoscope/Fiberoptic Scope

Against Awake Intubation

Awake Intubation if Unavoidable

Cricothyrotomy as Rescue

SGA as Rescue

Video laryngoscope w/ tube loaded onto flexible bronchoscope

Suction

nd Moisture Exchanger

High Efficiency Particulate Absorbing
19

100

2

2

7

22

23

7

27

27

92

\section{8}

36

9

\section{8}

27

73

\begin{tabular}{|l|l|}
\hline 36 & 64 \\
\hline & \\
\hline 36 & 64 \\
\hline
\end{tabular}

9

91

Legend: black $=$ yes $($ reported $) ;$ white $=$ no $($ not reported $)$. 


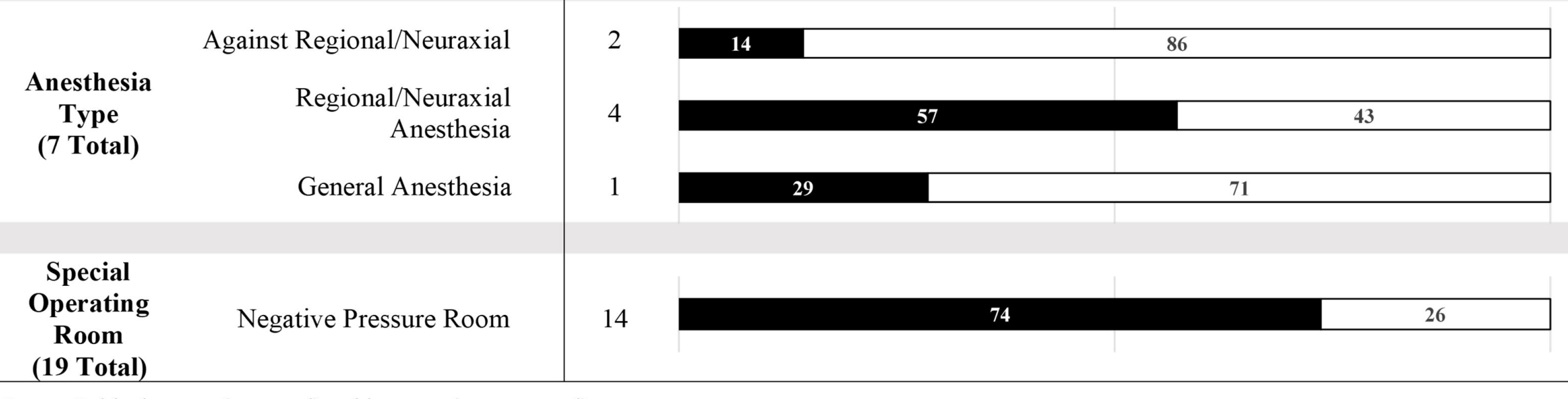

Legend: black = yes $($ reported $) ;$ white $=$ no $($ not reported $)$ 
Eye Protection

N95 Mask

Extubation

PPE

(4 Total)

\section{Extubation}

Technique

(10 Total)

Doffing

Processes

(19 Total)

Anti-tussive Techniques

Deep Extubation

Anti-emetic Prophylaxis

Deep Suction

Full-Body Shower

Avoid Touching Hair/Face

Hand Hygiene during/after

Doffing

Designated Environment

Spotter/Coach

PPE as a barrier to communication

\section{Non-technical}

Skills

(8 Total) oncise or Closed-

Loop communication

Debrief

Pre-brief/Pre-operative checklist

\section{4}

2

50 100

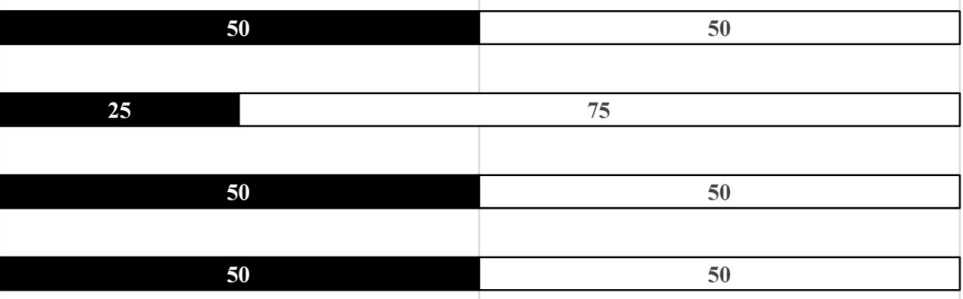

10

90

20

80

10

10

90

10

5 95

21 79

Legend: black $=$ yes $($ reported $) ;$ white $=$ no $($ not reported $)$ 